\title{
The Characteristics of SARS-CoV-2 Virus and Microbiological Diagnosis
}

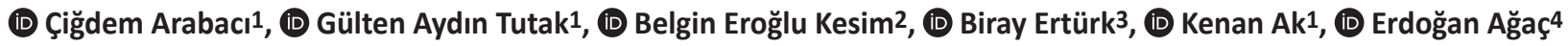 \\ 1 University of Health Sciences Turkey, Prof. Dr. Cemil Taşçıoğlu City Hospital, Clinic of Medical Microbiology Laboratory, Istanbul, Turkey \\ 2 Şişli Hamidiye Etfal Training and Research Hospital, Clinic of Genetic, Istanbul, Turkey \\ 3 University of Health Sciences Turkey, Prof. Dr. Cemil Taşçığlu City Hospital, Clinic of Genetic, Istanbul, Turkey \\ «University of Health Sciences Turkey, Prof. Dr. Cemil Taş̧̧ığlu City Hospital, Clinic of Infectious Diseases and Clinical Microbiology, Istanbul, Turkey
}

\section{Abstract}

World Health Organization, named the disease caused by Severe Acute Respiratory syndrome-coronavirus-2 coronavirus on 11 February 2020 as Coronavirus Disease-2019 (COVID-19). A person who has clinical symptom and a history of contact with a patient with confirmed COVID-19 is identified as a "possible case" and is expected to be confirmed by laboratory test. A confirmed case is asymptomatic/symptomatic suspected individual with a positive molecular test. Specific diagnosis is made by specific molecular tests on respiratory samples (orafarengeal/ nasopharyngeal swab/sputum/endotracheal aspirates and bronchoalveolar lavage). The virus can also be detected in the stool and in severe patients for a short time in the blood. The number of molecular tests that should be used in the case of a pandemic is rapidly increasing. At the beginning of the outbreak in Turkey, tests could only be performed in suspected patients in the central unit and then they began to be performed in other reference laboratories. Rapid antigen tests did not provide the desired performance, while rapid antibody tests were distributed to the field to support polymerase chain reaction tests and determine immunity. Microbiology Laboratory is indispensable in controlling the COVID-19 pandemic.

Keywords: SARS-CoV-2, COVID-19, microbiological diagnosis

\section{INTRODUCTION}

World Health Organization (WHO), named the disease caused by Severe Acute Respiratory syndrome-coronavirus-2 (SARS-CoV-2) coronavirus on 11 February 2020 as coronavirus disease-2019 (COVID-19). A person who has fever, sore throat, cough, or shortness of breath and a history of contact with a patient with confirmed COVID-19 is identified as a "possible patient" and is expected to be confirmed by laboratory test. Among the patients that meet the "possible patient" definition, patients with SARS-CoV-2 detected by molecular methods are defined as definite or confirmed patients. Specific diagnosis is made by specific molecular tests on respiratory samples (orafarengeal/ nasopharyngeal swab/sputum/endotracheal aspirates and bronchoalveolar lavage). The virus can also be detected in the stool and in severe patients for a short time in the blood. Validated and certified tests are not common at this time. The number of molecular tests that should be used in the case of a pandemic is rapidly increasing. At the beginning of the outbreak in Turkey, tests could only be performed in suspected patients in the central unit and then they began to be performed in other reference laboratories. Rapid antigen tests did not provide the desired performance, while rapid antibody tests were distributed to the field to support polymerase chain reaction (PCR) tests and determine immunity. Microbiology laboratory is indispensable in controlling the COVID-19 pandemic. Molecular tests have become widespread in our country, the number of tests performed has gradually increased, and the results can be 
obtained rapidly. In this way, support has been provided to the clinic and contact tracing.

\section{Coronaviruses and SARS-COV-2}

\section{History}

In 1937, Beaudette and Hudson identified the first coronavirus to cause respiratory infection in chickens (1). The first patient with human coronavirus (HCoV) infection was reported in 1960. This patient was suffering from the common cold (2). These coronaviruses have been divided into two different antigenic classes as HCoV 229E and HCoV OC43 (3). HCoV NL63 was defined in 2004 and HCoV HKU1 in 2005. In many studies, it was determined that especially HCoV NL-63 caused respiratory system infections in children (4). SARS caused by SARS-CoV-2, which alarmed WHO in February 2003, affected countries such as Hong Kong, Taiwan, Canada and Singapore the most after the Guandong region of China. The disease, which is thought to be transmitted first from bats to palm musk cats and from them to humans, reached 8422 patients in an eight-month period, with most of the patients from China. Nine hundred sixteen deaths were recorded and the mortality rate was determined as $10.8 \%$. After 2004, there has been no new case report related to SARS-CoV-2. Another coronavirus, Middle East respiratory syndrome (MERS)-CoV-2, was isolated in 2012 from the respiratory sample of a 60-year-old patient with acute pneumonia and kidney failure (MERS) in Saudi Arabia. Studies have found that dromedary camels act as reservoirs for this virus. As of February 14, 2020, it differs from other coronaviruses with more than 2.500 laboratory-approved patients and a high fatality rate of $34.4 \%$ (5). In late December 2019, Chinese health officials concentrated their work on the cluster of patients with atypical pneumonia occurring in people in a seafood and livestock market in Wuhan, Hubei Province of China. Fever, cough and chest discomfort and/or respiratory distress were reported most frequently in patients. The patients were diagnosed as having pneumonia with the help of radiological diagnostic tests such as chest X-rays and/ or computed tomography. By sequencing the bronchoalveolar lavage samples taken from patients, a variable betacoronavirus (betaCoV) showing approximately $80 \%$ sequence homology with the bat SARS virus-like coronavirus was identified (6). The virus was then isolated in cell culture and, according to detailed genetic analysis results, it was reported to show $89 \%$ sequence homology with bat SARS-like-CoVZXC21, 82\% with human SARS-CoV-2 and approximately $51.8 \%$ with MERS-CoV-2 (7). Variant CoV-2, named as SARS-CoV-2 by the International Committee of Taxonomy of Viruses, has been defined as the seventh CoV-2 that causes disease in humans and the third
CoV-2 that has been associated with severe respiratory diseases since $2003(8,9)$. WHO named the disease caused by SARS-CoV-2 coronavirus as COVID-19 on February 11, 2020 (10).

\section{General Features and Genome}

Coronaviruses belong to the order Nidovirales, family Coronaviridae, and subfamily Orthocoronavirinae. The Orthocoronavirinae subfamily involves four genera and is classified into multiple subgenera under these genera: Alphacoronavirus (alphaCoV), betaCoV, deltacoronavirus and gammacoronavirus. Only alphaCoV and betaCoV are known to infect humans. The coronavirus family is an enveloped, positive-polar RNA virus family with helical symmetry that causes disease in mammals and birds such as camels, cattle, and cats. Coronaviruses are the largest RNA viruses detected so far in terms of genome size and genetic complex structure. The large genome makes the virus less dependent on the host during replication. Its replication occurs in the cytoplasm of respiratory and gastrointestinal epithelial cells. Because it is seen as a crown, it is called "corona", which means crown in Latin (11). In Figures 1 and 2, the schematic view and electron microscopic view of SARS-CoV-2 are shown. SARS-CoV-2 is from betaCoV $2 \mathrm{~b}$ lineage. Coronaviruses are $65-125 \mathrm{~nm}$ in diameter and contain single-stranded RNA as nucleic acid, approximately $30 \mathrm{kbs}$ long. Like other CoVs, it is sensitive to ultraviolet light and heat. It can be inactivated with lipid solvents such as ether (75\%), ethanol, chlorine-containing disinfectant, peroxyacetic acid and chloroform other than chlorhexidine. Its single-stranded RNA contains 29,891 nucleotides and encodes 9,860 amino acids. Coronaviruses are capable of replicating their own genomes without integrating into the host genome. They owe this ability to

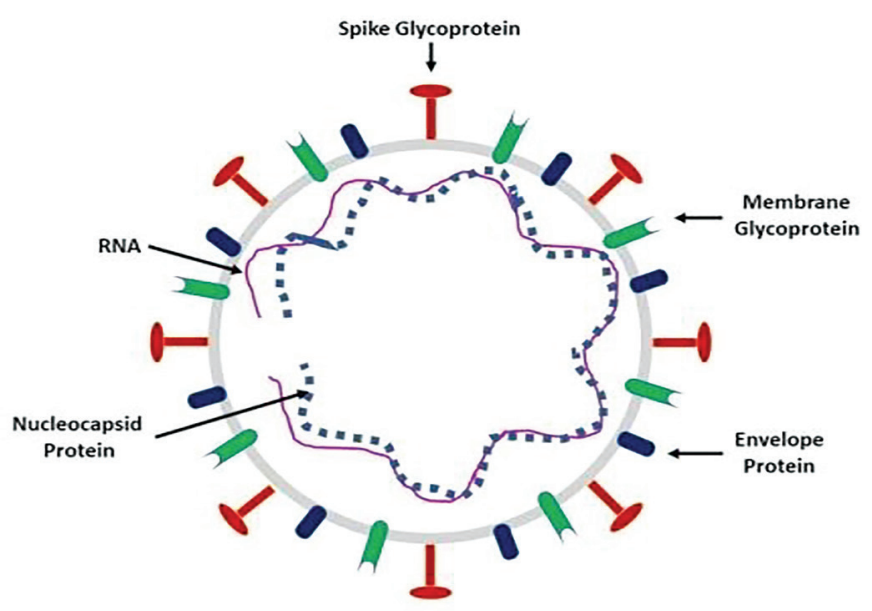

Figure 1. Schematic view of SARS-CoV-2

SARS-CoV-2: Severe Acute Respiratory syndrome-coronavirus-2 


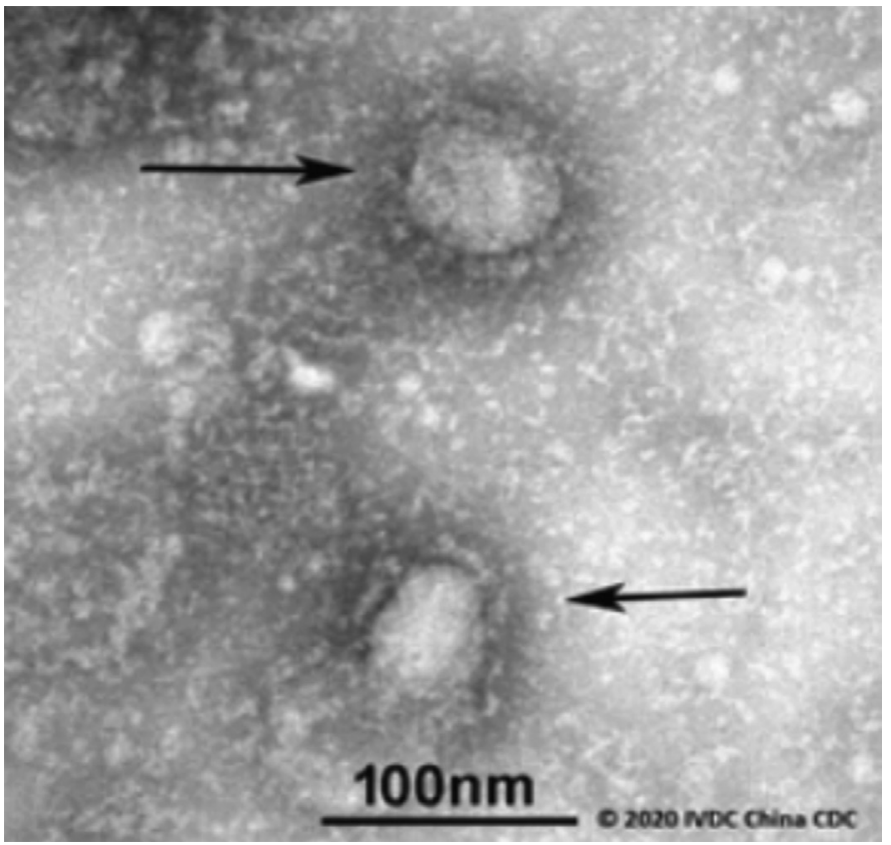

Figure 2. Electron microscopic view of SARS-CoV-2 (source: https // www.gisaid.org/last access date: 25.05.2020)

SARS-CoV-2: Severe Acute Respiratory syndrome-coronavirus-2

the RNA-dependent RNA polymerase (RdRp) gene that they have. RdRp gene enables these viruses to replicate their own genomes in the host's cytoplasm (12-14).

SARS-CoV-2 has a typical coronavirus structure. The envelopes of coronaviruses are made up of lipids.

Their genomes consist of structural, non-structural and accessory genes. In this context, in addition to the leader sequence, it contains the gene encoding the replicase protein required in the replication and transcription processes of RNA, the ORF1a and ORF1b encoding non-structural proteins, the $S$ gene encoding the spike (S) protein, the $M$ gene encoding the membrane (M) protein, the E gene encoding the envelope $(\mathrm{E})$ protein, the $N$ gene encoding the nucleocapsid $(\mathrm{N})$ phosphoprotein and various numbers of ORFs (replicase open reading frame), which encode genes of which functions are unknown.

Coronaviruses have four main structural proteins. These are S, $\mathrm{M}, \mathrm{E}$ and $\mathrm{N}$ proteins. All of the structural proteins are encoded from the 3' end of the viral genome. The $S$ glycoproteins are located outside the virion and give the virions their typical shape. By forming homotrimers, S proteins provide the formation of crown-shaped morphologies that give coronaviruses their name. The S protein is cleaved by the host cell's protease enzyme into two separate polypeptides S1 and S2. The S1 subunit forms a large part of the receptor binding domain of the S protein, while the S2 subunit forms the stem of the $S$ protein, which is likened to the spike model. $\mathrm{S}$ proteins bind to the virion membrane via their C-terminal transmembrane regions and also interact with $\mathrm{M}$ proteins. Virions bind to specific surface receptors on the plasma membrane of the host cell via the $\mathrm{N}$-terminal of $\mathrm{S}$ proteins [this receptor for SARS-CoV-2 is the angiotensin-converting enzyme 2 (ACE2) receptor] (15).

The coronavirus M glycoprotein has 3 transmembrane regions. M proteins are glycosylated in the golgi apparatus. This modification of the $\mathrm{M}$ protein is important in the fusion of the virion into the cell and gaining antigenic properties of the protein. The $M$ protein plays a key role in regenerating virions inside the cell. The $\mathrm{N}$ protein forms a complex by binding to genomic RNA, and then the $\mathrm{M}$ protein interacts with this complex in the endoplasmic reticulum-golgi apparatus intermediate compartment (ERGIC), triggering the formation of virions. This protein is important in the sensitization of the host cell by the virus, enabling the activation of the Interferon beta pathway by a toll-like receptordependent mechanism (16).

Coronavirus E proteins are small proteins that are approximately 76 to 109 amino acids long. Coronavirus E protein is an important virulence factor that plays a role in the accumulation of virions inside the cell and the separation of the virus from the cell by budding. It has been found that if there is no E protein in the virus, the viral load in the host is lower (17).

$\mathrm{N}$ protein is a helix and flexible phosphoprotein that can bind to viral genomic RNA. N protein has an important role in the structure of the virion, replication and transcription of coronaviruses; because it is localized both in the replication/ transcription region of coronaviruses and in the ERGIC region where the virus is collected. As a result of the crystallization studies of the $N$ protein of Avian infectious bronchitis virus and SARS coronaviruses, it has been shown that the $\mathrm{N}$ terminal of the protein binds to viral genomic RNA and the $\mathrm{C}$ terminal causes oligomerization during the accumulation of the virus (18). In addition, the $\mathrm{C}$ terminal of the $\mathrm{N}$ protein also interacts with the viral M protein. In studies, it has been observed that when viral $\mathrm{M}$ and $\mathrm{N}$ proteins are expressed together by means of mammalian expression vectors, $\mathrm{M}$ and $\mathrm{N}$ proteins interact in the cell to form structures similar to virions. The $\mathrm{N}$ protein also acts as an interferon antagonist, thereby inhibiting the virus from trying to be destroyed by the immune system (19).

The non-structural proteins (nsp) in the coronavirus genome are involved in a wide range from transcription of RNA to protein 
synthesis and modification. They are listed between 1-16. Among these, 3CL-pro, PL-pro, RdRp and helicase are important targets for the development of small inhibitor molecules due to their functional structures and enzyme active sites.

1- Papain-like proteinase (PL-pro) is responsible for cleaving the $\mathrm{N}$-terminal of the replication polyprotein to release nsp1, nsp2 and nsp3, which are responsible for correcting virus replication. In addition, studies have confirmed that PL-pro is important for antagonizing the innate immunity of the host. PL-pro, an indispensable enzyme during coronavirus replication and host infection, has been a popular target for coronavirus inhibitors (20).

2-3C-like main protease (3CL-pro); 3CL-pro, also known as nsp5, first automatically separates from polyproteins to produce mature enzymes and then separates nsp at specific regions to release nsp4 and nsp6. 3CL-pro directly mediates the maturation of nsp, which is necessary in the life cycle of the virus (21).

3- RNA-dependent RNA polymerase; RdRp is required for the genome replication of coronaviruses. RNA viruses containing RdRp can reproduce independently of the host and therefore reside in the cytoplasm. The protein itself is highly conserved, meaning that its structure is similar in all viruses containing the enzyme. Nsp12, a protein conserved in coronaviruses, is an RNA-dependent RNA polymerase and is the most important enzyme of the coronavirus replication/transcription complex (22).

The main reason for transmission from animal to human is the ingestion of an infected animal, then the virus is passed from infected individuals to healthy individuals by close contact. The disease is mainly transmitted by droplets. In addition, the droplets emitted by sick individuals through coughing and sneezing are transmitted by touching the mouth, nose or eye mucosa after contact with other people's hands. Since viruses can be detected in respiratory tract secretions of asymptomatic people, it can be contagious (23).

It binds to the ACE-2 receptor on the host cell surface via the virion $S$ protein and enters the cell and leaves its genomic RNA to the cytoplasm. Primarily, two viral replicase polyproteins are synthesized. These two large proteins are transformed into $16 \mathrm{nsp}$ with the help of proteases. These 16 nsp form double membrane vesicles and the replication and transcription complex. New virions are formed by combining newly formed structural proteins and genomic RNA in the ERGIC. The newly formed virions exit the cell using exosomes (24).

\section{Laboratory Diagnosis}

\section{Sampling and Transport}

Since it will cause aerosol scattering during the sampling process for molecular or other tests to be performed for the diagnosis of COVID-19, the personnel who will perform this procedure should use appropriate personal protective equipment (N95 mask, goggles, face protection). Health personnel assigned in this field are primarily informed by persons experienced in the prevention and control of infections (such as Infectious diseases specialist, microbiology specialist or infection control nurses). Training should be provided on infection control measures, use of personal protective equipment, appropriate sampling, storage and transportation of the sample under appropriate conditions. Ideally, it is recommended that first oropharyngeal sampling using oropharyngeal swab, then nasal sampling using the same swab should be performed and the swab should be placed in the same viral transport medium. Sputum, endotracheal aspirate samples and bronchoalveolar lavage samples can be used in patients with more severe respiratory disease. However, it should be kept in mind that the risk of transmission may be higher in this case (25). Figures 3 and 4 illustrate the nose and throat sampling using swab. Sampling and storage conditions are included in Table 1.

The fact that the if the first sample taken from patients who meet the definition of a possible case and whose infection findings continue worsening is an upper respiratory tract sample and the test result is negative, this does not exclude the suspicion of COVID-19 infection.

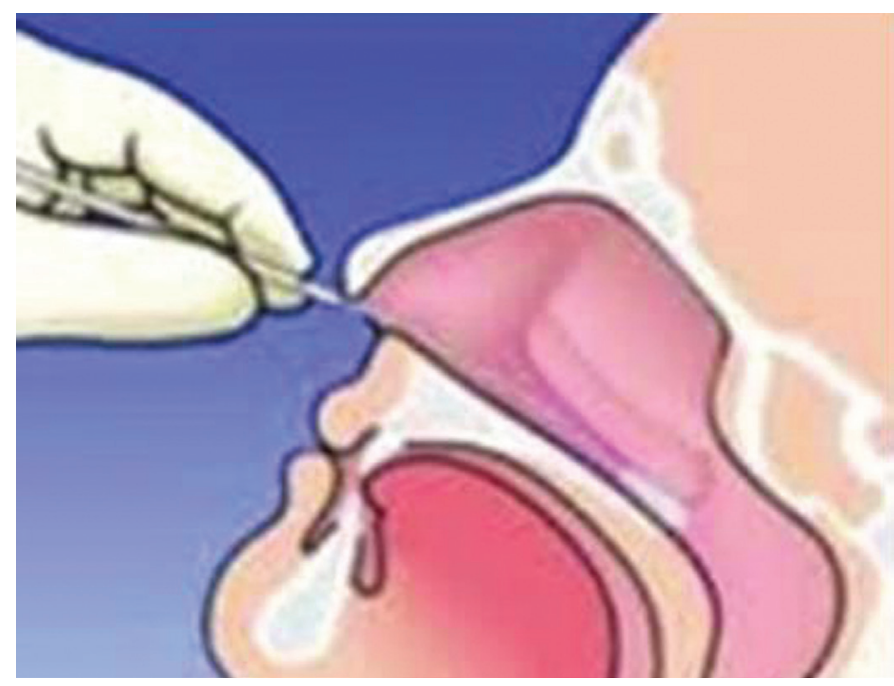

Figure 3. Taking a nasal swab 


\section{Diagnostic Tests}

In classical virology, diagnostic tests can be classified as cell culture, serology and molecular tests. Virus isolation is carried out under Biosafety level-3 (BGS-3) conditions. The WHO does not recommend virus culture and isolation for diagnostic purposes (27).

Today, there are 2 currently valid test methods for the diagnosis of COVID-19 (28).

1. Tests to detect viral antigens/viral RNA

\section{Serological tests}

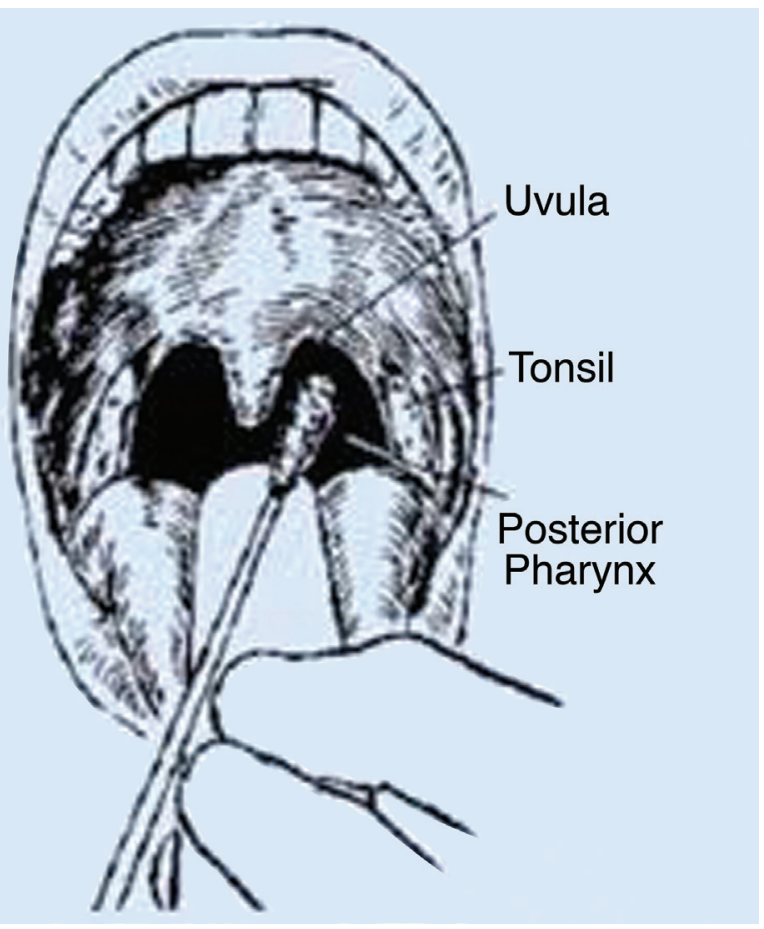

Figure 4. Taking a throat swap

\section{1- Rapid Diagnostic Tests Detecting Antigen}

The antigen test, a type of rapid diagnostic test, is based on detecting the presence of viral proteins expressed by SARS-CoV-2 in the respiratory sample. Since the detected antigens only occur when the virus is replicated, they are used to identify acute or early infection. How well the test works depends on a variety of factors, such as when the sample is taken, the viral load, and the quality of the sample. The US Food and Drug Administration announced that it approved the first antigen test (Sofia 2 SARS Antigen FIA) on 8.05.2020. Detected in this test is the SARSCoV-2 nucleocapsid protein. Rapid results are its most important advantage. However, reactive results do not exclude other coronaviruses and bacterial infections that cause cold. Tests with nonreactive results should be confirmed with a molecular test depending on the patient's condition (29). Advanced antigendetecting tests with sufficient performance can be used as a pretest to quickly identify patients who are likely to have potential COVID-19 and reduce the need for expensive molecular confirmatory testing. With the current limited data, WHO discourages the use of antigen tests to diagnose the disease.

\section{2- Viral RNA Tests}

The first preferred test method for the diagnosis of COVID-19 is viral nucleic acid determination with reverse transcriptionPCR (RT) (30). RNA can be obtained from upper respiratory tract (oropharynx and nasopharynx) swabs as well as lower respiratory tract samples such as bronchoalveolar lavage and sputum. It has been observed that samples taken from the nasopharynx give two times better results than samples taken from the oropharynx (31). If both samples are taken, it is recommended to combine the samples in a common tube,

\begin{tabular}{|l|l|l|l|}
\hline Table 1. Sampling and storage conditions (26) & $\begin{array}{l}\text { Conditions of transport of } \\
\text { material }\end{array}$ & Storage \\
\hline Type of sampling & Collection of material & $4{ }^{\circ} \mathrm{C}$ & $\begin{array}{l}\text { Within } 5 \text { days: } 4{ }^{\circ} \mathrm{C} \\
\text { More than } 5 \text { days: }-70{ }^{\circ} \mathrm{C}\end{array}$ \\
\hline $\begin{array}{l}\text { URT sampling (NP/OP swab and nasal } \\
\text { Swab) }\end{array}$ & Dacron or flocked swab (in VTM) & $\begin{array}{l}\text { Within } 48 \text { hours: } 4{ }^{\circ} \mathrm{C} \\
\text { More than } 5 \text { days: }-70{ }^{\circ} \mathrm{C}\end{array}$ \\
\hline $\begin{array}{l}\text { LRT sampling (sputum, tracheal } \\
\text { aspirate) }\end{array}$ & Sterile container & $4^{\circ} \mathrm{C}$ & $\begin{array}{l}\text { Within } 48 \text { hours: } 4{ }^{\circ} \mathrm{C} \\
\text { More than } 5 \text { days: }-70{ }^{\circ} \mathrm{C}\end{array}$ \\
\hline $\begin{array}{l}\text { Lung biopsy } \\
\text { Serum }\end{array}$ & $\begin{array}{l}\text { Sterile container with salt water } \\
\text { are collected for serological tests. } \\
\text { Acute phase: Within } 7 \text { days of } \\
\text { symptom onset. Recovery period: } \\
14 \text { days after collection in the } \\
\text { acute phase) }\end{array}$ & $4{ }^{\circ} \mathrm{C}$ & Within 5 days: $4{ }^{\circ} \mathrm{C}$ \\
\hline $\begin{array}{l}\text { VTM (viral transport medium) containing antibacterial and antifungal must be used to transport samples. Repeated freezing and thawing should be avoided. If VTM is not } \\
\text { available, sterile saline can also be used (In this case, the storage time at 2-8 }{ }^{\circ} \mathrm{C} \text { may be shorter than stated above). } \\
\text { URT: Upper respiratory tract, LRT: Lower respiratory tract, NP: Nasopharyngeal, OP: Oropharyngeal, VTM: Viral transport media }\end{array}$ & More than 5 days: $-70{ }^{\circ} \mathrm{C}$ \\
\hline
\end{tabular}


and it is known that the best result will be obtained by joint testing of both the lower and upper airways. SARS-CoV-2 RNA can also be isolated from stool, urine and blood samples, but these samples are less reliable than respiratory samples. It is recommended that upper respiratory tract samples be collected within a few days of the onset of symptoms. It has been reported that the virus peaks in the upper respiratory tract at the end of the first week, and in the lower respiratory tract at the end of the 3rd and 4th weeks in more severe patients (32). PCR tests should be run under BGS-2 conditions and with personal protective equipment. It is known that the PCR test does not detect any viruses other than SARS-CoV-2 by cross-reaction, and therefore it is a highly specific test. Although a definite rate cannot be given for its sensitivity, it has been reported that it ranges between 63-78\% (33). False negativities are common due to reasons such as low viral load or displacement of viral load, incorrect sampling, early or late sampling, antiviral use before testing, transport error, presence of PCR inhibitors in the environment, and viral genetic mutation. If the test is negative, repeating it at intervals is recommended to increase the sensitivity of the test $(26,32-34)$. It is of great importance to evaluate the clinical findings of the patients together with the RT-PCR results. For example, in a study of 4.880 patients conducted in Wuhan, the city where the pandemic started, it was reported that diagnostic value of RT-PCR increased by $19 \%$ in the presence of fever, and the diagnostic value of the test increased in advanced age and male patients (35). Again in a clinical observation of 82 patients made in China, when evaluated together with computed tomography, it was found that the sensitivity of RT-PCR increased from $79 \%$ to $94 \%$, and this situation was found to show that the presence of lung involvement like other clinical findings reduced the rate of false negativity of RT-PCR (36).

RT-PCR is a gold standard method used in the confirmation of COVID-19 infections despite its limitations (31). It enables the amplification of nucleotide sequences in the targeted regions of the RNA of the virus to become visible in real time with fluorescent dyes (37). $S$ and $N$ genes and non-structural RdRp and ORF $1 a / b$ genes are often used as target regions because they are genes that are conserved in the evolutional process, expressed and less involved in cross-reaction genes (38). When the diagnostic value of the RdRp/Hel region of SARS-CoV-2 is compared with the RdRp-P2 region, its sensitivity and specificity have been found to be higher $(38,39)$. Various number of different gene regions are used in different test kits and RT-PCR protocols suitable for these gene regions are performed. International viral transport mediums and kit specific viral nucleic acid buffers can be used for sample collection and transport. The samples taken should preferably be delivered to the laboratory at $4{ }^{\circ} \mathrm{C}$ and as soon as possible. The threshold cycle value (Threshold cycle/Ct) of target genes that can be evaluated at the end of PCR is below the limit value, indicating the presence of viral nucleic acid and means a positive result. The test results in an average of a few hours (34). Reactive reaction conditions, the number of genes analyzed can affect the sensitivity of the analysis. Optimization of PCR conditions by the laboratory is important. The clinical laboratory is required to perform a quality control in routine work using validated negative and positive samples. Apart from all these, the tested pathogen is an RNA virus. RNA is a molecule with low stability, it can be easily degraded by many enzymes after cell destruction, and it has a high risk of contamination. It is also known that RNA viruses are highly susceptible to mutation. Therefore, conducting the test on an RNA virus is an important factor that can highly affect the specificity of the test (40).

In conclusion, although real-time PCR is the first test used in the diagnosis of COVID-19, it should not be considered alone when making a decision for isolation and treatment due to false negative rates. Patients should be handled with a multidisciplinary approach and they should be evaluated together with all other data including clinical findings, lung CT, etc. (41).

\section{Sequence Analysis}

The virus genome ranges between 26-32 kb, contains 14 ORFs regions and encodes 26 proteins. S surface glycoprotein, $\mathrm{E}$ protein, $\mathrm{M}$ protein, and $\mathrm{N}$ protein are its main proteins (40).

Similarity of previously known SARS-CoV-2 (79\%) and MERS-CoV-2 (50\%) has been demonstrated by sequencing the genome data of the virus. It has been observed that SARS-CoV-2 shows a high level of homology to SARS-CoV-2 except for the differences in ORF1a and $S$ gene. The RNA sequence of the virus evaluated in phylogenetic studies have shown that the virus belongs to the betaCoV family. Thus, many information about the virus's origin, evolution, mechanisms, transmission routes and treatment could be predicted. The similarities and differences in the $S$ gene encoding the $S$ protein have given important clues about the binding of the virus to human ACE2 receptors and humanto-human transmission. By performing protein modeling studies of the obtained sequence, it has been reported that the $S$ protein has a high affinity for ACE2 receptors. Data such as human-to-human transmission dynamics, immune response, viral replication rate and virus mutation rate were obtained by determining the virus genome $(40,42)$. In another study, 10 SARSCoV-2 sequences obtained from different countries of the world 
were compared. No difference was observed in the sequences encoding the $\mathrm{M}$ and $\mathrm{N}$ proteins. Two amino acid variants in the $S$ protein sequence, one mutation in the $\mathrm{E}$ protein in one sample, and two possible single nucleotide polymorphisms were detected in the ORF1ab and ORF8 regions (43).

Similar studies of the RNA sequence of the virus are very valuable in terms of the course of the pandemic, prophylaxis and treatment of the disease (43). The genome sequencing of SARS-CoV-2 has also paved the way for vaccine technologies that can be developed against the virus. Vaccination studies on other viral pathogens, especially on DNA and mRNA, have paved the way for SARS-CoV-2 studies (44). The sequence of the ACE-FC protein has been reported to be a candidate gene in studies to be performed (44-46).

\section{3- Serology}

Another broad category of tests in the diagnosis of Covid-19 are serological tests that detect Immunoglobulin M (IgM), IgA, IgG and total antibodies (in blood). The occurrence of an antibody response to infection depends on host immunity and requires a certain period of time. Therefore, the age of the patient, nutritional status, severity of the disease, diseases such as HIV and the drugs used may be important in the formation of immunity. Since antibody tests cannot be used in the early stage of acute infection and do not affect the duration of treatment, their use in clinical diagnosis is limited. Tests showing antibody responses can be used for retrospective diagnosis by showing increased antibody levels in acute or convalescent periods in blood samples taken from patients with negative molecular test results for COVID-19 but with strong suspicion of COVID-19 (Figure 5). With current knowledge, time and more studies are needed on whether individuals infected with SARS-CoV-2 and have recovered later will be protected from SARS-CoV-2 in the future or how long protective immunity can last. Antibody tests for SARS-CoV-2;

1- It can be performed to monitor the contact person.

2- It can be used for serological monitoring at local, regional and national levels.

3- It is valuable in identifying people who have been exposed to the virus and may therefore be immune.

4- It can be used for diagnostic purposes to test individuals with clinical/radiological findings who are viral RNA-negative.

5- Information from serological tests can be used to guide decisions in individuals about returning to work, including individuals working in environments where they could potentially be exposed to SARS-CoV-2 (e.g. healthcare workers).

6- It can be useful in identifying individuals who may be sources for therapeutic or prophylactic neutralizing antibodies in plasma therapy.

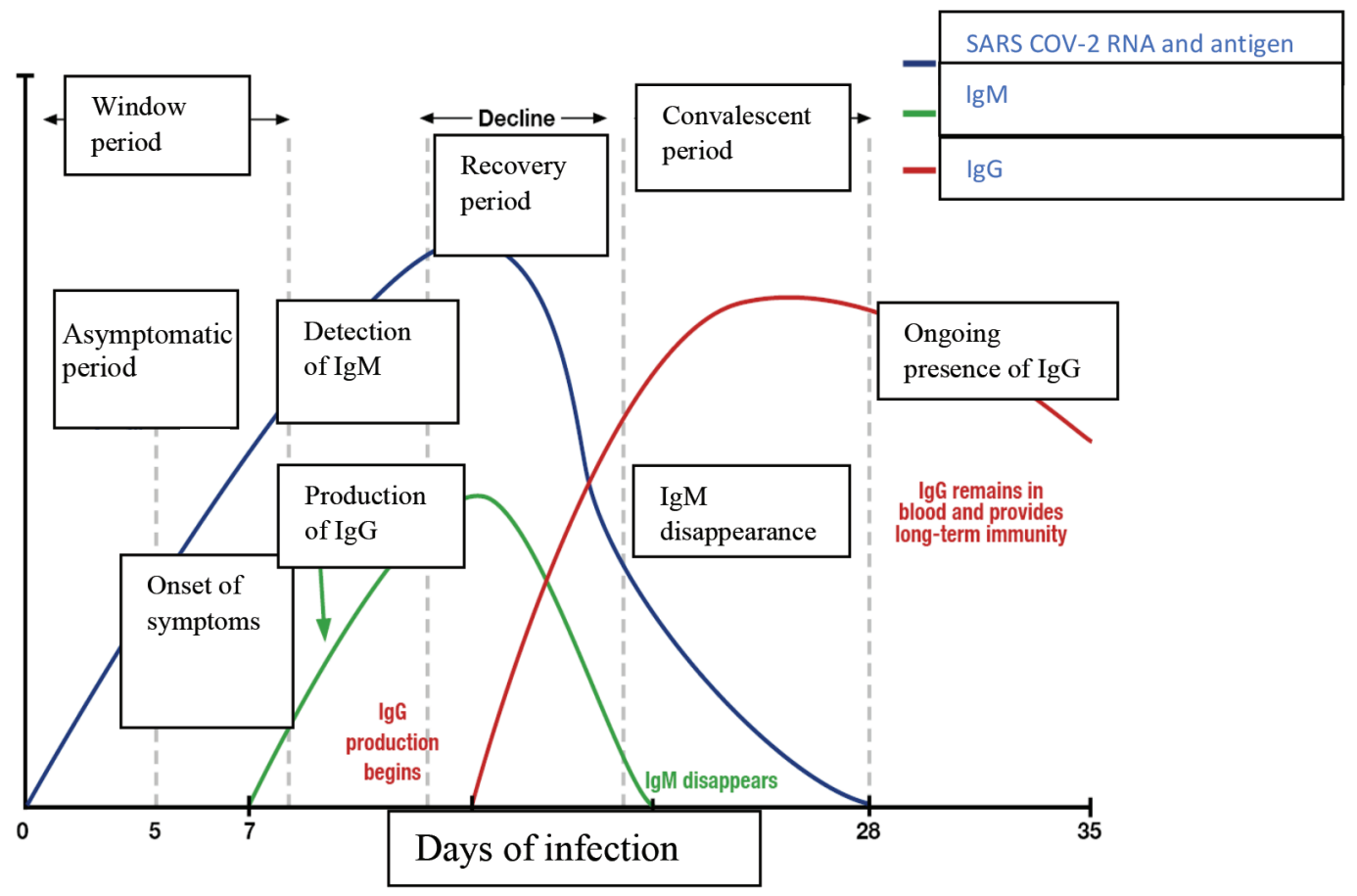

Figure 5. Relationship between antibody levels and disease course

SARS-CoV-2: Severe Acute Respiratory syndrome-coronavirus-2, IgM: Immunoglobulin M, IgG: Immunoglobulin G 
7- It can be used to evaluate response in vaccine studies and to determine immunity levels in the population.

In bedside chromatographic tests, monoclonal antibodies (mAb) are used to detect viral antigens in clinical samples, or cloned viral antigens are used to detect antibodies against the virus. In the "lateral flow" test method, there is a strip embedded in the cassette and the reagent fixed on the nitrocellulose membrane (a mAb for a viral antigen or a viral antigen recognized by the patient's antibodies). The patient's sample is added to the strip and reacts with the previously immobilized reagent. The samples to be investigated may be serum, plasma or, in some cases, whole blood. The test can often be performed with two to three drops of blood taken from the patient's fingertip. As a result of the positive reaction, a colored line is observed on the strip. Most tests also include a checkpoint or band so the results can be evaluated. Results are read visually and given qualitatively within minutes (47).

Enzyme immunoassay (EIA) tests, which take longer to develop, have less sensitivity and specificity than molecular methods, but they are easy to use and give results in a shorter time. However, the inability to reproduce the results obtained during their validation in clinical settings and the uncertainty of the results of the tests create serious diagnostic difficulties.

In the EIA method, the antibody bound to the antigen-antibody complex is marked with an enzyme and the enzyme activity is detected by measuring the intensity of the color change (enzyme-linked immunosorbent assay-ELISA) or the resulting light (chemiluminescent immunoassay-CLIA), and thus the antigen antibody reaction is detected. The direct method used in the search for antibodies by ELISA technique is also known as the "sandwich" or "double antibody" method (48). Proteins frequently selected as targets in tests are the $\mathrm{N}$ protein, which plays an important role in replication and transcription, and the "S" protein that facilitates viral entry into airway epithelial cells by binding to ACE2 expressed on the host cell surface (S1 and S2 in some tests) (49). In the study performed by jin et al. (50) using the CLIA method, they found that the sensitivity for IgM was $48.1 \%$, the specificity for IgM was $100 \%$, the sensitivity for IgG was $88.9 \%$, and the specificity for IgG was $90.9 \%$. In another study conducted by Pan et al. (51), it was stated that IgM, IgG and total antibody levels were at the highest level after the $15^{\text {th }}$ day.

The SARS-CoV-2/COVID-19 tests and their use are shown in Table 2 , and the clinical significance of the SARS-CoV-2/COVID-19 tests is shown in Table 3.

\section{COVID-19 Diagnostic Laboratory Studies and Test Algorithm in Our Country}

The first patient in our country was observed on March 11 and until today, 2.070,719 tests were performed, 164764 positive patients and 4563 deaths were reported (As of 01 June 2020).

First, PCR test for COVID-19 started to be performed in our country in only one test center (Public Health Agency of Turkey). With the increase in the number of tests, the number of test centers has also increased and as of 01 June 2020, 129 laboratories in 73 provinces have been authorized as COVID-19 Diagnostic Laboratories by the Ministry of Health. There are 2 types of PCR kits supplied to these laboratories by the Ministry of Health. The first of these is Biospeedy kit (Bioeks, Turkey) which targets viral RdRp. Virus RNA is isolated with VNAT solutions provided by the same brand. RT-PCR is provided

\begin{tabular}{|c|c|c|c|}
\hline Test & Status of individual & Usage & Benefit \\
\hline \multirow{2}{*}{$\begin{array}{l}\text { Viral nucleic acid } \\
\text { (RNA) Amplification } \\
\text { (nasopharyngeal swab, } \\
\text { oropharyngeal swab, } \\
\text { sputum, bronchoalveolar } \\
\text { lavage, other) }\end{array}$} & \multirow[b]{2}{*}{ SARS-CoV-2 infection } & $\begin{array}{l}\text { 1- Infection and transmission } \\
\text { status of the individual }\end{array}$ & Status of individuals, isolation and treatment \\
\hline & & $\begin{array}{l}\text { 2- Patient management and } \\
\text { control screenings to prevent } \\
\text { contamination }\end{array}$ & $\begin{array}{l}\text { People staying or working in healthcare sector or } \\
\text { care facilities for long-term }\end{array}$ \\
\hline \multirow{2}{*}{$\begin{array}{l}\text { Antibody detection } \\
\text { (Blood, plasma, serum, } \\
\text { fingertip blood) }\end{array}$} & \multirow[b]{2}{*}{$\begin{array}{l}\text { Prior SARS-CoV-2 } \\
\text { infection }\end{array}$} & $\begin{array}{l}\text { 1- Identification of suspected } \\
\text { patients (antigen, PCR negative } \\
\text { and previously infected) }\end{array}$ & Identification of potential immune individuals \\
\hline & & $\begin{array}{l}\text { 2- Identifying individuals with } \\
\text { neutralizing antibodies }\end{array}$ & Plasma therapy \\
\hline
\end{tabular}




\begin{tabular}{|l|l|l|l|}
\hline \multicolumn{4}{|l|}{ Table 3. Clinical significance of SARS-CoV-2/COVID-19 tests } \\
\hline \multicolumn{2}{|l|}{ Test result } & \multicolumn{2}{l|}{ Clinical significance } \\
\cline { 1 - 4 } PCR & IgM & IgG & \\
\hline+ & - & - & The patient may be in the window period of the infection \\
\hline+ & + & - & The patient may be in the early phases of the infection \\
\hline+ & + & $-/+$ & The patient is in the active phase of the infection \\
\hline+ & - & + & The patient may be in the late phase of infection or in recurrence phase. \\
\hline- & + & - & The patient may be in the early phase of the infection (PCR result may be false negative) \\
\hline- & - & + & The patient has had the infection and has recovered \\
\hline- & + & + & The patient may be in recovery phase or the PCR result may be false negative \\
\hline $\begin{array}{l}\text { SARS-CoV-2: Severe Acute Respiratory syndrome-coronavirus-2, CovID-19: Coronavirus Disease-2019, PCR: Polymerase chain reaction, IgM: Immunoglobulin M, IgG: } \\
\text { Immunoglobulin G }\end{array}$
\end{tabular}

in a single step and the amplification of SARS-CoV-2 RNA is performed in a single tube with internal control and read in two different channels.

The second PCR kit is an imported kit called Direct Detect (Coyote Bioscience, China). Isolation is achieved quickly with the reagents provided by the kit, and RT and amplification are carried out in one step. Differently, two different regions are targeted for amplification ( $\mathrm{N}$ and ORF1ab), and when internal control is considered, readings are made in three different channels, and positivity is diagnosed by observing amplification in both targeted regions. Observing amplification in only one region is not sufficient and requires repeating the test with the same or a different method.

Various antibody tests have also been distributed to laboratories authorized by the ministry of health in our country. Some of the kits can detect IgM and IgG type antibodies separately, while others detect total antibodies. Both of the two test categories for SARS-CoV-2 have been useful in this pandemic. If the rapid antigen test is represented by a product with increased sensitivity, it can be used in field pre-scans, in areas where PCR is impossible or inadequate. In breaking the pandemic, the power of the test is inevitable, and knowing the sensitivity of the diagnostic tests and increasing them if necessary will make valuable contributions to the clinic in terms of public health in starting contact tracing, follow-up of contacts and termination of contact tracing.

The first genome sequence of the SARS-CoV-2 shared in Turkey was provided open access by the Ministry of Health via GISAID database on March 25, 2020 (https //www.gisaid.org/last access date: 01.06.2020).

\section{COVID-19 Diagnostic Laboratory Studies in Our Hospital}

In our hospital, after we started following up patients with COVID-19, respiratory samples of these patients were sent to Public Health Laboratory no: 1, Kanuni Sultan Süleyman Training and Research Hospital, Turkey Institutes of Health Administration (TÜSEB), which started to perform SARS-CoV-2 PCR, and to COVID-19 PCR laboratories established in other training and research hospitals when necessary. Testing periods in external centers were 3-4 days on average. As a result of negotiations with TÜSEB in the first week of April 2020, a 3000-capacity COVID-19 PCR diagnostic center was established in our hospital. After the necessary logistical arrangements were made, this center started to work actively on 19 April 2020. While the preparations for the opening of the COVID-19 diagnostic center were continuing, 1,400 COVID-19 IgG and IgM rapid antibody card tests were sent to our hospital through the Ministry of Health. A special room and working team were established in the Infectious Diseases and Clinical Microbiology Outpatient Clinic. The training was completed by providing information on safe working principles and protection. Rapid antibody tests have started to be actively performed on April 14, 2020, and the personnel working in our hospital are still being screened. Seven biosafety cabinets, 4 PCR devices, other necessary PCR equipment and a young team of 10 people, experienced in biology, molecular biology and genetics departments of various universities, were sent to the COVID-19 diagnostic center established in our hospital. Initially, the Direct Detect (Coyote Bioscience, China) kit was used. Currently domestic Biospeedy (Bioeks, Turkey) kit is used. In our laboratory, samples from other hospitals affiliated to Beyoğlu Presidency are also studied. Our daily number of tests ranges from 300 to 800 . Almost all of the tests are studied during the day, and the average time for giving result is less than 24 hours. In our laboratory, 1047 rapid antibody tests were performed during this period and the positivity rate was $19.2 \%$. The number of SARS-CoV-2 PCR tests studied in the same period was 22277 . The positivity rate was on average $10.2 \%$ (the positivity rate, which was $23 \%$ at the beginning, decreased over time and fell below $5 \%$ ). 


\section{CONCLUSION}

As a result, in the COVID-19 pandemic, with molecular and serological diagnostic tests, it is possible to verify the patients in accordance with national guidelines and to effectively isolate positive cases. Accurate and reliable test results make it possible to prevent the disease, to get it under control quickly and to provide the necessary support to the patient in a timely manner. The power of the test is inevitable in breaking the pandemic, and knowing the sensitivity of the diagnostic tests and increasing them if necessary will provide valuable contributions to the clinic in contact tracing, treatment initiation, follow-up and treatment termination in terms of public health.

\section{Ethics}

Peer-review: Externally and internally peer-reviewed.

\section{Authorship Contributions}

Surgical and Medical Practices: C..A., G.A.T., B.E.K., B.E., K.A., E.A., Concept: C..A., B.E.K., B.E., K.A., E.A., Design: C..A., G.A.T., Data Collection or Processing: Ç.A., G.A.T., B.E.K., B.E., K.A., E.A., Analysis or Interpretation: G.A.T., B.E., E.A., Literature Search: C..A., G.A.T., B.E.K., B.E., K.A., E.A., Writing: C.A., G.A.T., B.E.

Conflict of Interest: No conflict of interest was declared by the authors.

Financial Disclosure: The authors declared that this study received no financial support.

\section{REFERENCES}

1. Fabricant J. The Early History of Infectious Bronchitis. Avian Dis 1998;42:648-50.

2. Hamre D, Procknow JJ. A new virus isolated from the human respiratory tract. Exp Biol Med 1966;121:190-3.

3. Mäkelä MJ, Puhakka T, Ruuskanen O, Leinonen M, Saikku P, Kimpimäki $\mathrm{M}$, et al. Viruses and bacteria in the etiology of the common cold. Clin Microbiol 1998;36:539-42.

4. Garbino J, Crespo S, Aubert DJ, Rochat T, Ninet B, Deffernez C, et al. A Prospective Hospital-Based Study of the Clinical Impact of Non-Severe Acute Respiratory Syndrome (Non-SARS) -Related Human Coronavirus Infection. Clin Infect Dis 2006;43:1009-15.

5. Park M, Thwaites RS, Openshaw PJM. COVID-19: Lessons from SARS and MERS. Eur J Immunol 2020;50:308-11.

6. Zhu N, Zhang D, Wang W, Xingwang L, Yang B, Song J, et al. A novel coronavirus from patients with pneumonia in China, 2019. New Engl J Med 2020;382:727-33.

7. Lu R, Zhao X, Li J, Niu P, Yang B, Wu H, et al. Genomic characterisation and epidemiology of 2019 novel coronavirus: implications for virus origins and receptor binding. Lancet 2020;395:565-74.
8. Gorbalenya AE, Baker SC, Babic RS, de Groot RJ, Drosten C, Gulyaeva AA, et al. Severe acute respiratory syndrome-related coronavirus: the species and its viruses - a statement of the Coronavirus Study Group. doi: 10.1101/2020.02.07.937862.

9. Peeri NC, Shrestha N, Rahman MS, Zaki R, Tan Z, Bibi S, et al. The SARS, MERS and novel coronavirus (COVID-19) epidemics, the newest and biggest global health threats: what lessons have we learned? Int J Epidemiol 2020;49:717-26.

10. World Health Organization. Naming the coronavirus disease (COVID-19) and the virus that causes it. Available from: URL: https://www.who. int/emergencies/diseases/novel-coronavirus-2019/technical-guidance/ naming-the-coronavirus-disease-(covid-2019)-and-the-virus-thatcauses-it

11. King AMQ, Adams MJ, Cartens EB, Leiowitz EJ, editors. Virus Taxonomy, the 9th report of the International Committee on Taxonomy of Viruses. San Diego, CA: Academic Press; doi:10.1016/B978-0-12-384684.

12. Van Boheemen S, De Graaf M, Lauber C, Bestebroer TM, Raj VS, Zaki AM, et al. Genomic characterization of a newly discovered coronavirus associated with acute respiratory distress syndrome in humans. MBio doi: 10.1128/mBio.00473-12

13. Lai CC, Shih TP, Ko WC, Tang HJ, Hsueh PR. Severe acute respiratory syndrome coronavirus 2 (SARS-CoV-2) and corona virus disease-2019 (COVID-19): the epidemic and the challenges. Int J Antimicrob Agents 2020;55:105924.

14. Hui DS, Azhar El, Madani TA, Ntoumi F, Kock R, Dar O, et al. The continuing 2019-nCoV epidemic threat of novel coronaviruses to global health - the latest 2019 novel coronavirus outbreak in Wuhan, China Int J Infect Dis 2020;91:264-6.

15. Racaniello V, Tuller D, Rey GU. Furin cleavage site in the SARS-CoV-2 coronavirus glycoprotein. Virology Blog Avaiable from: URL: https:// www.virology.ws/2020/02/13/furin-cleavage-site-in-the-sars-cov-2coronavirus-glycoprotein/

16. Neuman BW, Kiss G, Kunding AH, Bhella D, Baksh FM, Connelly S, et al. A structural analysis of $\mathrm{M}$ protein in coronavirus assembly and morphology. J Struct Biol 2011;174:11-22.

17. Schoeman D, Fielding BC. Coronavirus envelope protein: Current knowledge. Virol J doi: 10.1186/s12985-019-1182-0

18. Cong Y, Ulasli M, Schepersa H, Mauthea M, V'kovskic P, Kriegenburg $F$, et al. Nucleocapsid protein recruitment to replication-transcription complexes plays a crucial role in coronaviral life cycle. J Virol 2020;94.

19. Huang Q, Yu L, Petros AM, Gunasekera A, Liu Z, Xu N, et al. Structure of the N-terminal RNA-binding domain of the SARS CoV nucleocapsid protein. Biochemistry 2004;43:6059-63.

20. Chen X, Yang $X$, Zheng $Y$, Yang $Y$, Xing $Y$, Chen Z. SARS coronavirus papain-like protease inhibits thetype I interferon signaling pathway through interaction with the STING-TRAF3-TBK1 complex. Protein Cell 2014;5:369-81.

21. Pillaiyar T, Manickam M, Namasivayam V, Hayashi Y, Jung SH. An overview of severe acute respiratory syndrome-coronavirus (SARSCoV) 3CL protease inhibitors: peptidomimetics and small molecule chemotherapy. J Med Chem 2016;59:6595-628.

22. Elfiky AA. SARS-CoV-2 RNA dependent RNA polymerase (RdRp) targeting: an in-silico perspective. J Biomol Struct Dyn 2020;1-9.

23. T.C. Sağlık Bakanlığı. (14 Nisan 2020) COVID-19 (SARS-CoV-2 Enfeksiyonu) Rehberi. Available from: URL: https://www.tjod.org/wp-content/ uploads/2020/04/COVID-19_Rehberi-14.04.2020.pdf 
24. Ulaşlı M, Bayraktar R, Bozgeyi I. Replication of coronavirus. Gaziantep Med J 2013;19:141-8.

25. Zou, NEJM, 2020 HSGM, COVID 19 rehberi CDC, 2019-nCoV-Clinical Specimens Guidelines WHO, Laboratory testing for COVID-19, 2020.

26. Hong KH, Lee SW, Kim TS, Huh HJ, Lee J, Yeon Kim S, et al. Guidelines for Laboratory Diagnosis of Coronavirus Disease 2019 (COVID-19) in Korea. Ann Lab Med 2020;40:351-60.

27. WHO. Laboratory testing for coronavirus disease (COVID-19) in suspected human cases. 19 March 2020. Available from: URL: https://apps.who. int/iris/handle/10665/331501

28. Patel R, Babady E, Theel ES, Storch GA, Pinsky BA, George KS, et al. Report from the American Society for Microbiology COVID-19 International Summit, 23 March 2020: Value of Diagnostic Testing for SARS-CoV-2/ COVID-19. mBio 2020;11:e00722-20.

29. Coronavirus (COVID-19) Update: FDA Authorizes First Antigen Test to Help in the Rapid Detection of the Virus that Causes COVID-19 in Patients. Available from: URL: https://www.fda.gov/news-events/ press-announcements/coronavirus-covid-19-update-fda-authorizesfirst-antigen-test-help-rapid-detection-virus-causes\#: :text=The $\% 20$ U.S.\%20Food\%20and\%20Drug,use $\% 20$ in\%20the\%20ongoing\%20 pandemic

30. Li D, Wang D, Dong J, Wang N, Huang H, Xu H, et al. False-Negative Results of Real-Time Reverse-Transcriptase Polymerase Chain Reaction for Severe Acute Respiratory Syndrome Coronavirus 2: Role of DeepLearning-Based CT Diagnosis and Insights from Two Cases. Korean J Radiol 2020;21:505-8.

31. Wang W, Xu Y, Gao R, Lu R, Han K, Wu G, et al. Detection of SARS-CoV-2 in Different Types of Clinical Specimens. JAMA 2020;323:1843-4.

32. Loeffelholz MJ, Tang YW. Laboratory Diagnosis of Emerging Human Coronavirus Infections-the State of the Art. Emerg Microbes Infect 2020;9:747-56.

33. Zitek T. The Appropriate Use of Testing for COVID-19. West J Emerg Med 2020;21:470-2

34. Fang Y, Zhang H, Xie J, Lin M, Ying L, Pang P, et al. Sensitivity of Chest CT for COVID-19: Comparison to RT-PCR. Radiology 2020;296.

35. Liu R, Huan H, Liu F, Lv Z, Wu K, Liu Y, et al. Positive Rate of RT-PCR Detection of SARS-CoV-2 Infection in 4880 Cases from One Hospital in Wuhan, China, from Jan to Feb 2020. Clin Chim Acta 2020;505:172-5.

36. He LJ, Luo L, Luo ZD, Lyu JX, Ng MY, Shen XP, et al. Diagnostic Performance between CT and Initial Real-Time RT-PCR for Clinically Suspected 2019 Coronavirus Disease (COVID-19) Patients Outside Wuhan, China. Respir Med 2020;168:105980.

37. Kubista M, Andrade JM, Bengtsson M, Forootan A, Jonak J, Lind K, et al. The Real-Time Polymerase Chain Reaction. Mol Aspects Med 2006;27:95-125.
38. Chan JFW, Yip CCY, To KKW, Tang THC, Wong SCY, Leung KH, et al. Improved Molecular Diagnosis of COVID-19 by the Novel, Highly Sensitive and Specific COVID-19-RdRp/Hel Real-Time Reverse Transcription-PCR Assay Validated in Vitro and with Clinical Specimens. J Clin Microbiol 2020;58:e00310-20.

39. Lu R, Zhao X, Li J, Niu P, Yang B, Wu H, et al. Genomic Characterisation and Epidemiology of 2019 Novel Coronavirus: Implications for Virus Origins and Receptor Binding. Lancet 2020;395:565-74.

40. Wang H, Li X, Li T, Zhang S, Wang L, Wu X, et al. The Genetic Sequence, Origin, and Diagnosis of SARS-CoV-2. Eur J Clin Microbiol Infect Dis 2020;24:1-7.

41. Tahamtan A, Ardebili A. Real-Time RT-PCR in COVID-19 Detection: Issues Affecting the Results. Expert Rev Mol Diagn 2020:1-2.

42. Xu X, Chen P, Wang J, Feng J, Zhou H, Li X, et al. Evolution of the Novel Coronavirus from the Ongoing Wuhan Outbreak and Modeling of Its Spike Protein for Risk of Human Transmission. Sci China Life Sci 2020;63:457-60.

43. Chang TJ, Yang DM, Wang ML, Liang KH, Tsai PH, Chiou SH, et al. Genomic Analysis and Comparative Multiple Sequence of SARS-CoV2. J Chin Med Assoc 2020;83:537-43.

44. Prompetchara E, Ketloy C, Palaga T. Immune Responses in COVID-19 and Potential Vaccines: Lessons Learned from SARS and MERS Epidemic. Asian Pac J Allergy Immunol 2020;38:1-9.

45. Kruse RL. Therapeutic Strategies in an Outbreak Scenario to Treat the Novel Coronavirus Originating in Wuhan, China. F1000Res 2020;9:72.

46. Schweickert WD, PohIman MC, Pohlman AS, Nigos C, Pawlik AJ, Esbrook $\mathrm{CL}$, et al. Early Physical and Occupational Therapy in Mechanically Ventilated, Critically III Patients: A Randomised Controlled Trial. Lancet 2009;373:1874-82.

47. Li Z, Yi Y, Luo X, Xiong N, Liu Y, Li S, et al. Development and clinical application of a rapid IgM-IgG combined antibody test for SARS-CoV-2 infection diagnosis. J Med Virol 2020;92:1518-24.

48. Lou B, Li TD, Zheng SF, Su YY, Li ZY, Liu W, et al. Serology characteristics of SARSCoV-2 infection since exposure and post symptom onset. Eur Respir J doi: 10.1101/2020.03.23.20041707.

49. Burbelo PD, Riedo FX, Morishima C, Rawlings S, Smith D, Das S, et al. Detection of Nucleocapsid Antibody to SARS-CoV-2 is More Sensitive than Antibody to Spike Protein in COVID-19 Patients. J Infect Dis 2020;222:206-13.

50. Jin Y, Wang M, Zuo Z, Fan C, Ye F, Cai Z, et al. Diagnostic value and dynamic variance of serum antibody in coronavirus disease 2019. Int J Infect Dis 2020;94:49-52.

51. Pan Y, Li X, Yang G, Fan J, Tang Y, Zhao J, et al. Serological immunochromatographic approach in diagnosis with SARS-CoV-2 infected COVID19 patients. J Infect 2020;81:e28-32. 